\title{
EFFECT OF DIFFERENT FEEDING REGIMES ON: 1- DIGESTIBILITY AND PERFORMANCE OF GROWING BUFFALO HEIFERS
}

\author{
G. F. Shahin.; M. A. Abd El-Latif; Mona E. Farag and S. A. Ebrahim. \\ Animal Production Research Institute, Ministry of Agriculture, Dokki, Giza, Egypt.
}

(Received 10/2/2016, Accepted 6/4/2016)

\section{SUMMARY}

$\mathrm{T}$ This study aimed to evaluate the effect of different feeding levels on productive performance of growing buffalo heifers. Eighteen growing buffalo heifers $(156 \pm \ldots$ days old and $110 \pm \ldots \mathrm{kg}$ live body weight) were allocated randomly and equally to one of three treatments of 6 heads per each. Animals received their feeding allowance according to Kearl (1982) and the experiment was ended when the heifers reached to the first services: R1, $100 \%$ of the feeding allowances during the whole experimental period (control); R2, $80 \%$ of the feeding allowances to $300 \mathrm{~kg}$ body weight, then followed by $100 \%$ till the end of the experiment; and R3, 80\% of the feeding allowances during the whole experimental period. Digestibility trials were conducted to determine the feeding values of the experimental rations. Results indicated that treatments (R2 and R3) during the first phase recorded the lowest values of digestibility coefficients, feeding values, total body weight gain and daily gain than those fed on control diet. When the heifers in (R2) received $100 \%$ during the second phase, an improvement in heifers performance were observed in comparison with those in R3 treatment that recorded the longest periods $(\mathrm{P}<0.05)$ of age at puberty and $1^{\text {st }}$ service compared to those in other treatments. Increasing the feeding level was significantly $(\mathrm{P}<0.05)$ affected of the all blood serum parameters. Total feed cost and return economic efficiency indicted that the animals fed R2 ration had the superior economic efficiency, followed by those in R3 and then R1 was ranked the last. It could be concluded that feeding the weaned buffalo heifers on $80 \%$ of their feeding allowances until $300 \mathrm{~kg}$ body weight, followed by $100 \%$ of the allowances was more beneficial for the productive and reproductive performance and economical efficiency of growing buffalo heifers under Egyptian condition.

Keywords: feeding levels, buffalo heifers, productive and reproductive performance.

\section{INTRODUCTION}

The population of buffaloes in Egypt is about 3.1 million heads (FAO, 1998). Buffalo is considered the most important source of milk among the other dairy cattle in Egypt. They produced about 60 and $40 \%$ of the total milk and meat production, respectively (Agriculture Economy Research Institute, 1997). The critical problems of the buffalo are just related to the average daily gain and age at puberty, sexual maturity and first calving. Nutritional components especially energy and protein level (feeding levels) and requirement allowances are the most important factor affecting the physiological and metabolic status, growth rate at different ages and productive stages, weight at puberty and onset of first service, good body measurements and body condition insures maximum production and high reproduction efficiency and lifetime production of the buffalo heifers (Deutscher et al., 1986 and Shahin et al., 2004).

The main objective of feeding level and allowances of replacement dairy heifers is to produce the best possible dairy milk/products. Therefore the success of feeding in which offered the right nutritional allowances of replacement heifers cannot be measured in terms of average daily gain or feed efficiency but has to be assessed by the milk yield potential of the heifer as a cow. The main limiting factor for the milk yield potential of cows is the number of milksynthesizing cells in the mammary glands (Knight and Wilde, 1994).For the overall economy of the dairy industry, it is also important to minimize the costs of raising replacement heifers. The most effective way to reduce rearing costs is to lower the age at first calving. In most dairy cattle populations, the average age at firstcalving is between 24 and 30 months, but in some special cases heifers can calve as early as 15 to 16 mo of age. Thus, the scope for a reduction of age at first calving is largely possible. Age at onset of puberty is inversely related to growth rate. Therefore, heifers need to be raised on a high growth rate feeding regimen until puberty to obtain a substantial reduction of age at first calving. Unfortunately, high growth rates before puberty can have a 


\section{Shahin et al.}

negative influence on mammary growth and future milk production. Thus, to develop the optimum feeding and management regimen for heifers, it is necessary to understand the multi-relationship among onset of puberty, pubertal mammary development, and feeding level and to know the possible consequences for the milk yield potential. The main source of within-breed variation in age at onset of puberty is level of feeding (Moran et al., 1989, Robinson, 1990 and Schillo et al., 1992). Average age at first estrus decreased from 16.6 to 8.4 months as the growth rate increased from 450 to $850 \mathrm{~g} / \mathrm{d}$ (Foldager et al., 1988).

The effect of feeding level on mammary growth has been investigated in many experiments. The overall conclusion based on the available data is that a feeding level resulting in growth rates above 600 to $700 \mathrm{~g} / \mathrm{d}$ can have a permanent negative impact on mammary growth. Furthermore, the data suggest that the negative effect of feeding level is limited at the prepubertal phase of mammary development and that the period when mammary growth is sensitive to a high feeding level starts as early as 3 months of age, but the negative effect seemed to be most severe when heifers were fed a corn-based diet and very small when an alfalfa diet with a high protein content was consumed (Troccon and Petit, 1989, Waldo et al., 1989 and Sejrsen and Foldager, 1992). Also, data support the contention that the negative effect of feeding level on milk yield potential involves long-term effects of reduced pubertal mammary development.

This demonstrates that our knowledge on the effect of nutrition level during rearing on the future milk yield of heifers is incomplete and that it may bepossible to develop high growth rate feeding regimens for heifers. Experimental evidence suggests that the observed negative effects of feeding level on subsequent milk are due to impaired mammary development. Development of suitable high growth rate feeding regimens therefore requires understanding of the influence of nutrition on the physiological regulation of mammary development.

The present study aims to assess the possibility of applying the effect feeding level on productive performance of growing buffalo heifers raised.

\section{MATERIALS AND METHODS}

\section{Treatments and management}

This study was conducted at El-Gemmiza Agricultural Research Station, Animal Production Research Institute, Agriculture Research Center, Ministry of Agriculture, Egypt.

Eighteen growing buffalo heifers averaged $156 \pm \ldots$ days and $110 \pm \ldots$ kg live body weight were allotted randomly into three similar groups of six each. Control group (R1) was fed on $100 \%$ of the allowances up to the end of the experiment. The second group (R2) was fed on $80 \%$ of the allowances till heifers arrived to $300 \mathrm{~kg}$ live body weight $\left(1^{\text {st }}\right.$ period), and then received $100 \%$ of the allowances till the end of the experiment, while the third group (R3) was fed on $80 \%$ of the allowances during the whole experimental period $\left(1^{\text {st }}\right.$ and $2^{\text {nd }}$ periods). All nutritional allowance of all groups were calculated according to Kearl, (1982) and the experiment was ended when the heifers reached the first services. All heifer groups were fed on 40: 60 concentrate: roughage ratio until the end of the experiment. The offered roughage was consisted of $35 \%$ corn silage, $10 \%$ berseem hay $(\mathrm{BH})$ and $15 \%$ rice straw (RS). All heifers were kept under semi-open sheds, while individually feeding system was applied. The concentrate feed mixture (CFM) was offered twice daily before check for oestrous at 7 am and $4 \mathrm{pm}$, while roughage was offered at 8 am and $5 \mathrm{pm}$. Minerals blocks and fresh water were available all the day time. During the experiment, feed intake was daily recorded, while live body weight was biweekly determined before the morning feeding and feed allowance was adjusted accordingly.

\section{Sampling and analysis}

Daily intake of CFM, corn silage, BH and RS was recorded throughout the experiment period. Representative samples of offers ingredients, refusals and feces were analyzed according to the A.O.A.C. (1995). Chemical analysis of different feedstuffs and calculated composition of the experimental rations are presented in Table 1.

Blood samples were taken from all experimental heifers at the end of the first and second periods at three hours after morning feeding and left at room temperature for 45-60 minutes, then centrifuged at 4000 r.p.m for 15 minutes. Blood serum was separated and stored at $-20^{\circ} \mathrm{C}$ until later analyses. Blood samples were analyzed for total protein (Henry, 1964), albumin (Doumaset al., 1971) and urea (Patton 
and Crouch, 1977), while globulin was calculated by subtraction of serum albumin from total serum protein. Glucose and cholesterol were quantified in blood serum by using kits of Spinreact, S.A.U. Ctra. Santa Coloma, 7 E-17176 SantEsteve de Bas (GI), Spain by means of spectrophotometer. Direct RIA technique was performed for assessment of total serum tri-iodothyronine (T3) and thyroxine (T4) concentrations. Ready antibody-coated tube kits (Total T3 RIA KIT. REF IM 1699-2013-08-14-IM3287) and (Total T4 RIA KIT. REF IM 1447-2013-08-14-IM3286) were used according to the procedure outlined by the manufacturer.

Two digestibility trials were conducted using all heifers in the experimental groups. The first trials was carried out at the end of the first period, while the second one was conducted at the end of the second period. Fecal grape samples were taken from heifers at three successive days and composted for each animal to determine total apparent digestibility using silica (McDonald et al., 1995) as an internal marker. The data were analyzed according to statistical analysis system, (SAS) User's Guide, (1998). Differences among means was carried out by using Duncan multiple range tests (Duncan, 1955).

Table (1): Chemical analysis of the feedstuffs and calculated chemical composition of the experimental rations.

\begin{tabular}{lcccccc}
\hline Item & DM & CP & EE & CF & NFE & Ash \\
\hline CFM & 89.82 & 16.24 & 2.34 & 13.75 & 61.95 & 5.72 \\
Corn silage & 36.65 & 7.42 & 1.71 & 23.58 & 52.81 & 14.48 \\
Berssem hay & 89.51 & 13.68 & 0.52 & 28.25 & 45.22 & 12.33 \\
Rice Straw & 89.14 & 3.21 & 1.02 & 38.25 & 40.50 & 17.02 \\
*Ration (TMR) & 71.08 & 10.95 & 1.74 & 22.32 & 53.85 & 11.13 \\
\hline
\end{tabular}

-TMR: Total mixed ration consists of 40: 60 concentrate: roughage ratio and roughage consisted 35\% corn silage, $10 \%$ berseem hay and $15 \%$ rice straw.

\section{RESULTS AND DISCSSION}

\section{Nutrients Digestibility:}

During the first period, data of Table (2) clearly showed that animals in R1 recorded higher $(\mathrm{P}<0.05)$ digestibility values of DM, CP, EE and NFE than those in R2 and R3, while the difference between animals in R2 and R3 group was not significant. This may be due to the high energy and protein level (feeding levels) that appeared to improve physiological and metabolic status and increased the activity of microorganism in the rumen. However, animals fed on R2 and R3 recorded a higher CF digestibility than those in R1. Concerning feeding values which expressed as TDN and DCP, it could be noticed that animals in R1 recorded higher values than those in R2 and R3 with nosignificant difference. It was noted a linear increase in digestibility coefficient and feeding values with increasing the level of feed intake. The digestibility coefficients and feeding values of experimental rations during the second period are shown in Table (2). Data showed that digestibility coefficients of DM and CP were higher $(\mathrm{P}<0.05)$ in $\mathrm{R} 1$ compared to those in R2 and R3. Also, insignificant differences among treatments respecting EE digestibility were observed. The TDN did not significantly different among treatments during the second period.

Animals fed on R3 ration recorded the lowest $(\mathrm{P}<0.05)$ NFE digestibility and lowest DCP than those of other treated groups. On contrary, animals in $\mathrm{R} 3$ recorded higher $(\mathrm{P}<0.05)$ digestibility values of $\mathrm{CF}$ than those of R2 and R3, while the difference between animals in R2 and R3 was not significant. The highest digestion coefficient of CF in R3 may be due to that the fact of decreasing DM intake that could increase the retention time of feed in the rumen, which in turn led to an improvement in digestibility. Similar findings were reported by Ahamed et al. (2003), El-Ashry et al. (2003), Shahin et al. (2004) and Shahin, (2007) who demonstrated that the increase of feeding level improved the digestibility of all nutrients except for CF. However, Steingasset al. (1994) found that the nutrient digestibility decreased linearly with the increase of feeding level. 
Shahin et al.

Table (2): Effect of feed intake level and dietary treatment on nutrients digestibility during $1^{\text {st }}$ and $2^{\text {nd }}$ periods.

\begin{tabular}{|c|c|c|c|c|c|c|c|c|}
\hline & \multicolumn{4}{|c|}{ First period } & \multicolumn{4}{|c|}{ Second period } \\
\hline & R1 & R2 & R3 & SE & R1 & $\mathrm{R} 2$ & R3 & $\mathrm{SE}$ \\
\hline & $100 \%$ & $80 \%$ & $80 \%$ & & $100 \%$ & $100 \%$ & $80 \%$ & \\
\hline \multicolumn{9}{|c|}{ Feed intake, kg/head/day } \\
\hline DM & 7.54 & 6.03 & 6.03 & & 8.10 & 8.10 & 6.48 & \\
\hline TDN & 4.74 & 3.68 & 3.68 & & 5.02 & 5.02 & 3.97 & \\
\hline $\mathrm{CP}$ & 0.826 & 0.66 & 0.66 & & 0.89 & 0.89 & 0.71 & \\
\hline \multicolumn{9}{|c|}{ Digestibility, \% } \\
\hline $\mathrm{DM}$ & $72.03^{\mathrm{a}}$ & $68.19^{\mathrm{b}}$ & $68.79^{\mathrm{b}}$ & 0.13 & $72.49^{\mathrm{a}}$ & $70.95^{\mathrm{b}}$ & $68.74^{\mathrm{b}}$ & 0.38 \\
\hline $\mathrm{CP}$ & $69.46^{\mathrm{a}}$ & $65.87^{\mathrm{b}}$ & $65.27^{\mathrm{b}}$ & 0.41 & $68.93^{\mathrm{a}}$ & $66.92^{\mathrm{b}}$ & $65.36^{\mathrm{b}}$ & 0.54 \\
\hline $\mathrm{CF}$ & $52.90^{\mathrm{b}}$ & $56.35^{\mathrm{a}}$ & $56.96^{\mathrm{a}}$ & 1.01 & $52.27^{\mathrm{b}}$ & $54.15^{\mathrm{b}}$ & $57.42^{\mathrm{a}}$ & 0.68 \\
\hline $\mathrm{EE}$ & $73.75^{\mathrm{a}}$ & $69.41^{\mathrm{b}}$ & $69.79^{\mathrm{b}}$ & 0.42 & 73.53 & 71.51 & 70.34 & 0.61 \\
\hline NFE & $75.42^{\mathrm{a}}$ & $71.51^{\mathrm{b}}$ & $71.37^{\mathrm{b}}$ & 0.36 & $75.64^{\mathrm{a}}$ & $74.73^{\mathrm{a}}$ & $71.57^{\mathrm{b}}$ & 0.66 \\
\hline \multicolumn{9}{|c|}{ Feeding values } \\
\hline TDN & 62.80 & 61.02 & 61.02 & 1.57 & 62.78 & 62.46 & 61.27 & 1.42 \\
\hline $\mathrm{DCP}$ & 7.61 & 7.21 & 7.15 & 0.24 & $7.50^{\mathrm{a}}$ & $7.33^{\mathrm{a}}$ & $6.16^{\mathrm{b}}$ & 0.33 \\
\hline
\end{tabular}

Overall notes, animals received a $80 \%$ of their allowances during the first period (R2) recorded the lowest values of digestibility coefficients and feeding values than those received a $100 \%$ of the allowances (R1), while receiving $100 \%$ of the allowances during the second period has led to an improvement in digestibility coefficients and feeding values than those received $80 \%$ that will be reflected on productive and reproductive performance (Table 4 and 5).

\section{Blood serum parameters:}

Results of blood parameters of the different experimental treatments for the first and second periods are shown in Table (3). Animals received high level of feeding appeared to show higher $(\mathrm{P}<0.05)$ glucose level than those fed on the other feeding treatments. Similar results were obtained by Ali et al. (2014) who revealed that blood glucose was significantly increased in growing heifers fed high verse low energy diets. The present values of serum glucose are within the normal values of ruminants that ranged between 68.15 to $80.28 \mathrm{mg} / \mathrm{dl}$.

Similar trends were occurred with the concentrations of total protein, albumin, globulin and ureain which the higher values were associated with R1 over the first period and R1 and R2 on the second period. These results are in agreement with those obtained by El-Ashry et al. (2007 and 2008) and may be due to the higher digestibility and feeding value (DCP) as shown in Table (2). These findings confirmed the concept of Mosaad and Derar (2009) who reported that energy and protein metabolism is closely intertwined in ruminants. This complex balanced system is further complicated as most of the carbohydrates consumed by ruminants are fermented in the rumen to VFAs and limited glucose is available to absorption. Therefore, glucogenesis is of great importance to ruminants. Propionate is the major source of glucose (27-55\%), and glucogenic amino acids supplies a significant amount (15-36\%) of the glucogenic materials. Increased concentration of blood urea with advancing age over the first and second periods indicated a normal physiological fuel shift (Khan et al., 2007 and 2008). The present values of serum total protein and urea concentration are within the normal values of ruminants that ranged between 6.45 to $8.01 \mathrm{~g} / \mathrm{dl}$ and 41.88 to $53.01 \mathrm{mg} / \mathrm{dI}$, respectively. Dietary protein can affect the concentration of albumin and globulin (Rowlandset al., 1974). The present data of serum albumin or globulin among the different experimental groups (Table 3) clearly indicated that serum albumin and globulin were affected by feeding levels (TDN and DCP) in diets. These results are in contrast with those findings by Ibrahim et al. (2005) who found that serum albumin was insignificantly lower in Baladi 
calves and their cross bred with feeding high levels of TDN and DCP compared to those fed low levels of TDN and DCP. The present results concerning serum cholesterol concentration with heifers fed different level of TDN and DCP are presented in Table (3). The average cholesterol concentration ranged from 64.56 to $70.58 \mathrm{mg} / \mathrm{dl}$. Serum cholesterol of heifers fed high feeding level was significantly increased in comparison with those fed low feeding level. These results are in harmony with those of Schricket al. (1990) who found that cows fed low energy had lower concentrations of serum cholesterol. However, the mean values of T3 and T4 in blood serum of growing buffalo heifers fed different feeding level are shown in Table (3). The data indicated that $\mathrm{T} 3$ and $\mathrm{T} 4$ concentrations were significantly $(\mathrm{P}<0.05)$ higher in animal received high feeding level than those fed low one. Values of T3 and T4 are proportionally correlated with the levels of feeding. These findings may reflect a good feed utilization, absorption and metabolism for heifers fed high feeding levels than those fed the low ones. Collier et al. (1984) reported that the pituitary thyroid axis is an important physiological factor controlling metabolic processes and milk secretion. Thyroid hormones (T3 and T4) synergize with other hormones to promote growth and development of the mammary gland and maintenance of lactation.

Table (3): Some blood serum parameters of growing buffalo heifers fed the experimental groups.

\begin{tabular}{lcccccccc}
\hline & \multicolumn{4}{c}{ First period } & \multicolumn{5}{c}{ Second period } \\
\cline { 2 - 9 } & R1 & R2 & R3 & SE & R1 & R2 & R3 & SE \\
\hline Glucose, mg/dI & $79.55^{\mathrm{a}}$ & $68.29^{\mathrm{b}}$ & $68.15^{\mathrm{b}}$ & 1.88 & $80.28^{\mathrm{a}}$ & $78.95^{\mathrm{a}}$ & $68.54^{\mathrm{b}}$ & 2.02 \\
Total protein, g/dI & $7.98^{\mathrm{a}}$ & $6.47^{\mathrm{b}}$ & $6.45^{\mathrm{b}}$ & 0.15 & $8.01^{\mathrm{a}}$ & $7.85^{\mathrm{a}}$ & $6.51^{\mathrm{b}}$ & 0.18 \\
Albumin, g/dI & $4.03^{\mathrm{a}}$ & $3.38^{\mathrm{b}}$ & $3.38^{\mathrm{b}}$ & 0.37 & $4.18^{\mathrm{a}}$ & $4.07^{\mathrm{a}}$ & $3.32^{\mathrm{b}}$ & 0.27 \\
Globulin, g/dI & $3.95^{\mathrm{a}}$ & $3.09^{\mathrm{b}}$ & $3.07^{\mathrm{b}}$ & 0.21 & $3.83^{\mathrm{a}}$ & $3.78^{\mathrm{a}}$ & $3.19^{\mathrm{b}}$ & 0.22 \\
Urea, mg/dI & $52.48^{\mathrm{a}}$ & $41.88^{\mathrm{b}}$ & $42.08^{\mathrm{b}}$ & 4.65 & $53.01^{\mathrm{a}}$ & $51.89^{\mathrm{a}}$ & $43.81^{\mathrm{b}}$ & 4.95 \\
Cholesterol, mg/dI & $70.19^{\mathrm{a}}$ & $64.56^{\mathrm{b}}$ & $64.62^{\mathrm{b}}$ & 2.84 & $70.58^{\mathrm{a}}$ & $68.78^{\mathrm{a}}$ & $65.19^{\mathrm{b}}$ & 3.22 \\
T3, nmol/L & $1.28^{\mathrm{a}}$ & $1.09^{\mathrm{b}}$ & $1.08^{\mathrm{b}}$ & 0.12 & $1.30^{\mathrm{a}}$ & $1.27^{\mathrm{a}}$ & $1.10^{\mathrm{b}}$ & 0.21 \\
T4, nmol/L & $71.78^{\mathrm{a}}$ & $64.45^{\mathrm{b}}$ & $64.38^{\mathrm{b}}$ & 3.11 & $72.25^{\mathrm{a}}$ & $71.56^{\mathrm{a}}$ & $64.55^{\mathrm{b}}$ & 2.78 \\
\hline
\end{tabular}

$-a, b$ and $c$ : Means in the same row with different superscripts are significant $(P<0.05)$.

Generally, results in Table (3) during the first and second periods showed that increasing the feeding level of ration tended to increase $(\mathrm{P}<0.05)$ all traits of blood serum parameters.

\section{Productive performance:}

Data of growth performance are presented in Table (4). At the first period, total weight gain of the three dietary treatments was almost similar. Concerning the age at puberty, at the first period, it could be observed that animals fed $80 \%$ feeding level (R2 or R3) had delayed puberty $(\mathrm{P}<0.05)$ than those fed (R1). However, animals received $100 \%$ feeding level (R1) had a higher average daily gain than those fed the other feeding levels. This may be due to the differences in feeding levels, digestibility coefficients and feeding values during this period that were associated with large different age of heifers at puberty. These results are in agreement with those achieved by El-Ashry et al. (2008), Etman et al. (2007) and Shahin (2004). Data presented in Table (4) showed the DM intake of buffalo heifers at different stages of animals' growth. Animals received $80 \%$ feeding level (R2 or R3) appeared to show a significant lower in TDN, CP and DCP intake compared to those received R1. This may be due to the differences in feeding levels, digestibility coefficients and feeding values during this period. Concerning the feed conversion ratio, expressed as the amount of intake of DM, TDN or CP per $\mathrm{kg}$ gain, was almost similar among different feeding levels. Animals in R3 group appeared to have a better feed conversion (DCP/gain) compared to those in other groups (R1 and R2). Improved feed conversion ratio (DCP/gain) for R3 group might be attributed mainly to the difference in daily gain and nutrients digestibility with lower feed intake level. These results are in harmony with those obtained by El-Ashry et al. (2008), Etman et al. (2007) and Shahin (2004). 
Table (4): Daily gain, feedintake and feed conversion of growing buffalo heifers fed the experimental rations during the first period.

\begin{tabular}{|c|c|c|c|}
\hline \multirow[t]{2}{*}{ Item } & \multicolumn{3}{|c|}{ Groups } \\
\hline & $\mathrm{R} 1$ & $\mathrm{R} 2$ & R3 \\
\hline Initial body weight, $\mathrm{kg}$ & $112.83 \pm 4.22$ & $110.17 \pm 3.34$ & $109.33 \pm 4.83$ \\
\hline Weight at puberty, $\mathrm{kg}$ & $296.17 \pm 6.72$ & $298.0 \pm 5.52$ & $302.33 \pm 11.22$ \\
\hline Initial age, days & $156.21 \pm 12.82$ & $158.58 \pm 14.59$ & $153.83 \pm 11.69$ \\
\hline Age at first period (puberty), days & $428.50^{\mathrm{b}} \pm 22.81$ & $504.49^{\mathrm{a}} \pm 24.22$ & $504.74^{\mathrm{a}} \pm 21.82$ \\
\hline Total gain, $\mathrm{kg}$ & $183.34 \pm 11.49$ & $187.83 \pm 10.86$ & $193.0 \pm 12.08$ \\
\hline Average daily gain, $\mathrm{kg}$ & $0.673^{\mathrm{a}} \pm 0.045$ & $0.543^{b} \pm 0.02$ & $0.550^{\mathrm{b}} \pm 0.034$ \\
\hline \multicolumn{4}{|l|}{ Average intake, $\mathrm{kg} / \mathrm{head} /$ day } \\
\hline $\mathrm{DM}$ & $7.54^{\mathrm{a}}$ & $6.03^{\mathrm{b}}$ & $6.03^{\mathrm{b}}$ \\
\hline TDN & $4.74^{\mathrm{a}}$ & $3.68^{\mathrm{b}}$ & $3.68^{\mathrm{b}}$ \\
\hline $\mathrm{CP}$ & $0.826^{\mathrm{a}}$ & $0.66^{\mathrm{b}}$ & $0.66^{\mathrm{b}}$ \\
\hline $\mathrm{DCP}$ & $0.574^{\mathrm{a}}$ & $0.435^{\mathrm{b}}$ & $0.431^{\mathrm{b}}$ \\
\hline \multicolumn{4}{|l|}{ Feed conversion: } \\
\hline $\mathrm{Kg} \mathrm{DM} / \mathrm{kg}$ gain & 11.20 & 11.10 & 10.96 \\
\hline $\mathrm{Kg}$ TDN / kg gain & 7.04 & 6.78 & 6.69 \\
\hline $\mathrm{Kg} \mathrm{CP} / \mathrm{kg}$ gain & 1.23 & 1.21 & 1.20 \\
\hline $\mathrm{Kg}$ DCP / kg gain & $0.853^{\mathrm{b}}$ & $0.801^{\mathrm{ab}}$ & $0.784^{\mathrm{a}}$ \\
\hline
\end{tabular}

$a, b$ and $c:$ Means in the same row with different superscripts are significant $(P<0.05)$.

Data regarding the productive and reproductive performance at second period are shown in Table (5). Body weight at puberty and $1^{\text {st }}$ service were almost similar among feeding treatments. This was associated with large difference in the age at puberty and $1^{\text {st }}$ service. At the second period, concerning the age at $1^{\text {st }}$ service, it could be observed that animals in $\mathrm{R} 3$ had older age at $1^{\text {st }}$ service $(\mathrm{P}<0.05)$ than those in the other treatments. Total body weight gain (from puberty to $1^{\text {st }}$ service) for heifers fed R1 diet was significantly higher that those fed R2 diet, while the difference was not significant in comparison with those fed R3 diet.

In the second period when animals in R2 received $100 \%$ after $80 \%$ of feeding levels, they had a highest average daily gain $(\mathrm{P}<0.05)$, followed by those in $\mathrm{R} 1$ and then $\mathrm{R} 3$ recorded the lowest one. This is largely due to the compensatory phenomena that usually happened after a restriction feeding at the early growing stage of heifers, particularly with different in feeding level and systems, digestibility coefficients and feeding values during this period that was associated with large different in heifers age at $1^{\text {st }}$ service. These results are in agreement with those reported by El-Ashry et al. (2008), Etmanet al. (2007) and Shahin, (2004). On the other hand, Almquist and Amann (1976) reported that weight and age at different reproductive performance stages would be attributed to a genetic character. Animals received $100 \%$ feeding level (R1 or R2) appeared to have a higher TDN, CP and DCP intake compared to R3. This may be due to the differences in feeding levels and systems, digestibility coefficients and feeding values during the experimental period. Feed conversion expressed as the intake of DM, TDN, CP or DCP required per kg gain (Table 5) showed that the heifers fed $\mathrm{R} 3$ ration had a better $(\mathrm{P}<0.05)$ feed conversion ratio, followed by those fed $\mathrm{R} 2$ ration, while those fed $\mathrm{R} 1$ ration showed a poorest feed conversion ratio. This might be due mainly to the different of daily gain and nutrients digestibility with lower feed intake level. These results are in harmony with those obtained by El-Ashry et al. (2008), Etman et al. (2007), Shahin (2004) and Ali et al. (2014) who reported that heifers offered high energy and protein levels (feeding level) had a significantly higher total body weight gain and daily gain than those had low energy and protein levels. 
Table (5): Productive and reproductive performance of growing buffalo heifers fed the experimental rations (second period).

\begin{tabular}{|c|c|c|c|}
\hline \multirow[t]{2}{*}{ Item } & \multicolumn{3}{|c|}{ Groups } \\
\hline & R1 & $\mathrm{R} 2$ & R3 \\
\hline Weight at puberty, $\mathrm{kg}$ & $296.17 \pm 6.72$ & $298.0 \pm 5.52$ & $302.33 \pm 11.22$ \\
\hline Weight at first service, $\mathrm{kg}$ & $347.83 \pm 10.25$ & $339.33 \pm 13.41$ & $349.0 \pm 12.86$ \\
\hline Total gain, $\mathrm{kg}$ & $51.66^{\mathrm{a}}$ & $41.33^{\mathrm{b}}$ & $46.67^{\mathrm{ab}}$ \\
\hline Age at puberty, days & $428.50^{\mathrm{b}} \pm 22.81$ & $504.49^{\mathrm{a}} \pm 24.22$ & $504.74^{\mathrm{a}} \pm 21.82$ \\
\hline Age at onest first service, days & $517.25^{\mathrm{b}} \pm 26.22$ & $571.69^{\mathrm{a}} \pm 36.81$ & $594.66^{\mathrm{a}} \pm 25.77$ \\
\hline Average daily gain, $\mathrm{kg}$ & $0.582^{\mathrm{a}} \pm 0.064$ & $0.615^{\mathrm{a}} \pm 0.042$ & $0.519^{\mathrm{b}} \pm 0.051$ \\
\hline \multicolumn{4}{|l|}{ Average intake, $\mathrm{kg} / \mathrm{head} /$ day } \\
\hline $\mathrm{DM}$ & $8.10^{\mathrm{a}}$ & $8.10^{\mathrm{a}}$ & $6.48^{\mathrm{b}}$ \\
\hline TDN & $5.02^{\mathrm{a}}$ & $5.02^{\mathrm{a}}$ & $3.97^{\mathrm{b}}$ \\
\hline $\mathrm{CP}$ & $0.887^{\mathrm{a}}$ & $0.887^{\mathrm{a}}$ & $0.710^{\mathrm{b}}$ \\
\hline $\mathrm{DCP}$ & $0.611^{\mathrm{a}}$ & $0.594^{\mathrm{a}}$ & $0.464^{\mathrm{b}}$ \\
\hline \multicolumn{4}{|l|}{ Feed conversion: } \\
\hline $\mathrm{Kg} \mathrm{DM} / \mathrm{kg}$ gain & $13.92^{\mathrm{b}}$ & $13.17^{\mathrm{ab}}$ & $12.49^{\mathrm{a}}$ \\
\hline $\mathrm{Kg}$ TDN / kg gain & $8.63^{b}$ & $8.16^{\mathrm{ab}}$ & $7.65^{\mathrm{a}}$ \\
\hline $\mathrm{Kg} \mathrm{CP} / \mathrm{kg}$ gain & $1.52^{\mathrm{b}}$ & $1.44^{\mathrm{ab}}$ & $1.36^{\mathrm{a}}$ \\
\hline $\mathrm{Kg}$ DCP / kg gain & $1.05^{\mathrm{b}}$ & $0.966^{\mathrm{ab}}$ & $0.894^{\mathrm{a}}$ \\
\hline
\end{tabular}

$a, b$ and $c:$ Means in the same row with different superscripts are significant $(P<0.05)$.

Generally, results in Table (4 and 5) during the first and second periods clearly indicated that increasing the feeding level was positively $(\mathrm{P}<0.05)$ affected total body weight gain and daily gain, and the age at puberty and $1^{\text {st }}$ service. It could be observed that the animals fed $80 \%$ feeding level were recorded the longest period of age at onset first service $(\mathrm{P}<0.05)$ compared to the other treatments.

\section{Economic efficiency:}

Economic efficiency data are presented in Table (6). It was previously mentioned that the average daily gain was significantly $(\mathrm{P}<0.05)$ increased with increasing feeding level. However, total gain and price of total gain was insignificantly higher in experimental ration (R3) in comparison with the other treatments. Concerning the period between initial age and age at first service (day) and relative of age in all period efficiency, it could be observed that the animals fed a low feeding level (R3) was recorded the longest periods $(-22.10 \%)(\mathrm{P}<0.05)$ compared to animals fed a high feeding level $(\mathrm{R} 1)$.

Concerning the total feed intake and feed cost, it was concluded that animals fed a control diet (R1) had a higher $(\mathrm{P}<0.05)$ feed intake and consequently higher feed cost, followed by those in $\mathrm{R} 3$, while those in $\mathrm{R} 2$ recoded the lowest values. However, the return and relative economic efficiency indicted that animals fed R3 ration had a superior economic efficiency, followed by those fed R1, and then R2 rations. On the other hand, the effect of feeding level on mammary growth has been previously investigated. Based on the available data, a feeding level that resulted in a growth rate above 600-700 g/d can have a permanent negative impact on mammary growth. Furthermore, the data suggested that the negative effect of feeding level is limited to the prepubertal phase of mammary development and that the period when mammary growth is sensitive to a high feeding level starts as early as 3 months of age. This results seem to agree with those of Mohamed et al. (1999), Etmanet al. (2007), El-Ashry et al. (2008), Ali et al. (2014) and Abd El-Hafeez et al. (2015). 
Table (6): Economical efficiency of growing buffalo heifers fed different feeding levels treatments

\begin{tabular}{lccc}
\hline & & Groups & R3 \\
\cline { 2 - 4 } & R1 & R2 & 239.67 \\
Total gain (all periods), kg & 235 & 229.16 & 0.544 \\
Daily gain, kg & 0.651 & 0.555 & 9107 \\
Price of total gain, LE & 8930 & 8708 & 101.98 \\
Relative price of total daily gain efficiency & $100 \%$ & 97.51 & 440.83 \\
Period between initial age and age at first & 361.04 & 413.11 & -22.10 \\
service, days & 100 & -14.42 & 2698.67 \\
Relative of age in all period efficiency & & & 3643.20 \\
Total DMI, kg/h & 2771.94 & 2630.16 & 5463.80 \\
Total feeding cost, LE & 3742.12 & 3550.72 & 105.32 \\
Return, LE & 5187.88 & 5157.28 & 99.41 \\
Relative economic efficiency & 100 & & \\
\end{tabular}

- Dietary ration which consists of 40\% CFM plus 35\% corn silage plus $10 \%$ berseem hay and $15 \%$ rice straw. The price of feedstuffs: $C F M /$ ton $=2500 \mathrm{LE}$; corn silage / ton $=450 \mathrm{LE} ;$ berseem hay $/$ ton $=1400 \mathrm{LE}$ and rice straw/ ton $=350 \mathrm{LE} ;$ dietary ration $/$ ton $=1350 \mathrm{LE}$ and live body weight $/ \mathrm{kg}=38 \mathrm{LE}$.

* Return = Price of total daily gain, LE - Total feeding cost, LE

\section{CONCLUSION}

It could be concluded that feeding growing buffalo heifers at $80 \%$ of feed allowances according to Kearl (1982) recommendations of TDN and DCP over the whole experimental period were more suitable for productive and reproductive performance.

\section{REFERENCES}

Abd El-Hafeez, A.M. ; M.A.E. Ali;A.A.S. Mahgoub; M. Y. Mohamed and S.A. Ibrahim (2015). The productive and reproductive efficiency of the pregnant heifers, milked and suckled baladi cows under different levels of nutrition. Egyptian J.Nutrition and Feeds (2015), 18(2) Special Issue: 77-93.

Ali, M.A.E.; A.M. Abd El-Hafeez S.A. Ibrahim and Safaa N. Abd El-Azem (2014).The productive and reproductive efficiency of cow Baladi heifers under different levels of nutrition. Egyptian J. Nutrition and Feeds, 17(1): 51.

Almquist, J. O. and R. p. Amann (1976). Reproduction capacity of daily bulls Xl. Puberty characteristics and postpuberty changes in production of semen and sexual activity of Holstein bulls ejaculated frequently. J. Dairy Sci., 59: 986.

Agricultural Economic Research Institute (1997). Annual Report for Agriculture Production, Ministry of Agriculture, Egypt (In Arabic).

Ahamed, B. M.; H. T. Taie; M. M. Bendary and K. F. Abdel-Lateif (2003). Influence of dietary corn silage on digestibility, performance and economical efficiency of dairy cattle. Egyptian J. Nutrition and Feeds (Special Issue): 587.

A.O.A.C. (1995).Official Methods of Analysis.15th ed. Association of Official Analytical Chemists, Arlington, Virginiall USA. 
Collier, R.J.; J.P. McNamara; C.R. Wallace and M.H. Dehoff (1984).A review of endocrine regulation of metabolism during lactation. J. Anim. Sci., 59:498. Coulon

Doumas, B., W. Watson, and H. Biggs.(1971). Albumin standars measurement of serum with bromocresol green. Clinical Chemistry Acta, 31:37.

Deutscher, G.H; L. L. Zerfoss and DC.Clanton (1986).Time of zeranol implantation on growth, reproduction and calving of beef heifers.J. of Animals Sci., 62: 4, 875.

Duncan (1955). Multiple range and multiple F test. Biometric, 11: 1-42.

El-Ashry, M. A.; H. M. Khattab; K. E. I. Etman and S. K. SAYED (2003). Effect of two different energy and protein levels on productive and reproductive performance of lactating buffaloes.Egyptian $\mathrm{J}$. Nutrition and Feeds 6(Special Issue) 491.

El-Ashry, M. A.; A. E.M. Khinizy; G. F. Shahin and M. E. Faarg (2007). Effect of two different concentrate levelsin the ration on meat productive from buffalo calves. Egyptian J. Nutrition and Feeds 10 (2)(Special Issue) 439.

El-Ashry, M. A.; G. F. Shahin ; T. I. El-Monayer and S. B. Mehany (2008). Effect of feeding different concentrate: corn silage ratio on body weight and age at conception of buffalo heifers. Egyptian J. Nutrition and Feeds 11 (2)277.

Etman , K. E. I; G. F. Shahin; A. A. El-Tahan and S. K. Sayed (2007). Studies on feeding allowances during different growth periods for crossed Friesian heifers. Egyptian J. Nutrition and Feeds 9 (2): 19.

FAO (1998).Production year book, Vol. 52 FAO Publ., Rome.Italy, pp 35.

Foldager, J.; K. Sejrsen, and J. T. Sorensen (1988). The effect of plane of nutrition on growth and feed utilization in RDM and SDM heifers-revision of energy requirements for growth.(In Danish with English summary and subtitles.)Report 648, Natl. Inst. Anim. Sci., Foulum, Denmark.

Henry R. J. (1964). Clinical chemistry Harber and Row publishers, New york p.181.

Ibrahim, S.; A.M. El-Gaafarawy; S.M. El-Sheikh; Hanaa, A. El-Koussy and S.A. Swiefy (2005). Feeding and meat production-related parameters in Baladi, Abondance $\times$ Baladi and Tarentaise $\times$ Baladi fattened calves. Proc. 2nd Conf. Anim. Prod. Res. Inst., Sakha 27-29 Sep.: 107.

Kearl, L. C. (1982). Nutrients allowance of ruminants in developing countries. International Feedstuffs Institute Utah Agricultural Experiment Station Utah State University, Logan Utah December.

Khan, M. A., H. J. Lee, W. S. Lee, H. S. Kim, S. B. Kim, K. S. Ki, S. J. Park, J. K. Ha, and Y. J. Choi $\left(2007_{\mathrm{b}}\right)$. Starch source evaluation in calf starter: I. Feed consumption, body weight gain, structural growth, and blood metabolites in Holstein calves. J. Dairy Sci. 90:5259.

Khan, M. A., H. J. Lee, W. S. Lee, H. S. Kim, S. B. Kim, S. B. Park, K. S. Baek, J. K. Ha, and Y. J. Choi (2008). Starch source evaluation in calf starter: II. Ruminal parameters, rumen development, nutrients digestibilities and nitrogen utilization in Holstein calves. J. Dairy Sci. 91:1140.

Kholif, S.M.; T.A. Morsy; A.A. Abedo; N. El-Bordeny and M.M. Abdo (2011). Milk production and composition, milk fatty acid profile, nutrients digestibility and blood composition of dairy buffaloes fed crushed flaxseed in early lactation. Egyptian J. Nutrition and Feeds, 14 (3): 409.

Lapierre, H.; G. Pellitclerc; D. Petitclerc; P. Dubreuil; J. Morisset; P. Gaudreau; Y. Couture and P. Brazeau (1990). Effect of human growth hormone releasing factor and (or) thyrotropin-releasing factor on hormone concentrations and milk production in dairy cows. Can. J. Anim. Sci., 70:175.

McDonald, P.; R. A. Edward and J. F. D. Greenbolgh (1995).Animal nutrition ( th $^{\text {th }}$ edition).Oliver and Boyd publisher.

Moran, C., J. F. Quirke, and J. F. Roche. 1989. Puberty in heifers: A review. Anim. Reprod. Sci. 18:167.

Mosaad G.M. and D.R. Derar (2009).Effect of dietary energy and phosphorus on nutrients digestibility, blood constituents, and ovarian structures in ewes. Veterinary World, 2(12): 456.

Patton C. J. and S. R. Crouch (1977).Anal. Chem., 49: 464.

Robinson, J. J. 1990. Nutrition in the reproduction of farm animals.Nutr. Res. Rev. 3:253. 


\section{Shahin et al.}

Rowlands, G.J.; W. Little; R. Manston and S.A. Dew (1974). The effect of season on the composition of the blood of lactating and non-lactating cows as revealed from reported metabolic profile test on 24 dairy herds. J. Agric. Sci., 83: 27.

SAS (1998). Statistical analysis system SAS user's Guide: Statistics. SAS institute Inc. editors, Cary,N

Schillo, K. K., J. B. Hall, and S. M. Hileman. 1992. Effects of nutrition and season on the onset of puberty in the beef heifer.J. Anim. Sci. 70:3994.

Schrick, F.N.; J.C. Spitzer; T.C. Jenkins; D.M. Henricks and T.G. Althen (1990).Effect of dietary energy restriction on metabolic and endocrine responses during the estrous cycle of the suckled beef cow. J. Anim. Sci., 68:3313.

Sejrsen, K., and J. Foldager(1992). Mammary growth and milk production capacity of replacement heifers in relation to diet energy concentration and plasma hormone levels.Acta Agric. Scand. Sect. A Anim. Sci. 42:99.

Shahin, G. F. (2007). Response of pregnant Egyptian Crossbred Friesian heifers to feeding whole maize silage rations with different levels of feed intake.Egyptian J. Nutrition and Feeds 10 (2) Special Issue: 183-192.

Shahin, G. F. (2004). Effect of dietary energy level on nutrient utilization, productive and reproductive performance of growing buffalo heifers. Egyptian J. Nutrition and Feeds 7 (2): 143.

Shahin, G. F.; A. A. Zaki and H. M. Yousf (2004).Effect of feeding level on growth, nutrient digestibility and feed efficiency for buffalo calves. Egyptian J. Nutrition and Feeds 7 (1): 11-12.

Steingass, H.; A. Haas; R. Stetter; T. Jilg and A. Susenbeth (1994). Influence of feeding level on nutrient and energy digestibility in sheep and cattle. Wirtschaftseigene-Futter.40:2-3, 215.

Troccon, J. L., and M. Petit (1989).Criossance des genisses de renouvellementet performances ulterieures. INRA Prod. Anim.2:55.

Waldo, D. R., A. V. Capuco, and C. E. Rexroad(1989). Replacement heifer growth rate affects milk producing ability. Feedstuffs, 27 November, p 15. 


\title{
تأثيرأنظمة مستوى التظذية على : 1- معاملات هضم و الأداء الإتتاجي لعجلات الجاموس النامي
}

\author{
جمال فاروق شاهين ، مجدي عبد الرحمن عيد اللطيف ، منى أحمد السيد فرج و صلاح السيد عطية \\ معهُ بحوث الإتتاج الحيوانسي - مركز البحوث النزراعية - وزارة النزراعة.
}

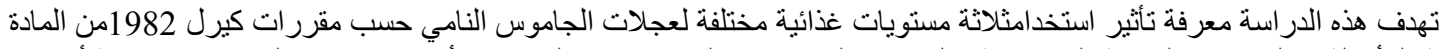

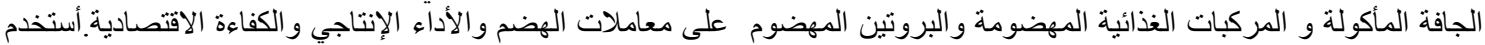

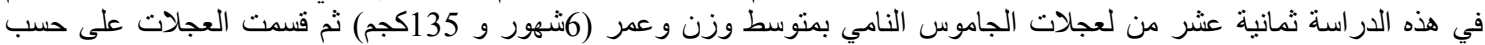

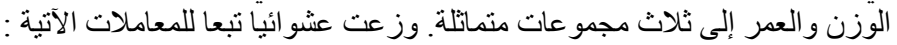

المعاملة الأولى : فيها تناولت العجلات غذاء يحتوى على 100\% من الاحتياجات الغذائية حسب مقررات كيرل 1982 واستمرت حتى نهاية التجربة (كنترول).

المعاملة الثانية : فيها تناولت العجلات غذاء يحتوى على 80\% من من الاحتياجات الغذائية حسب مقررات كيرل 1982 حتى وزن العجلات إلى 300 كجم ثم يرتفع مستوى التغذية إلى 100\% من الاحتياجات الغذائية حسب مقرر الثبات كيرل 1982 وتستمر حتى نهاية

المعاملة الثالثة : فيها تناولت العجلات غذاء يحتوى على 80\% من الاحتياجات الغذائية حسب مقررات كيرل 1982 واستمرت حتى

نهاية التجربة.

وقد استمرت التجربة حتى وصول العجلات إلى أول تلقيحه تم خلالها دراسة أداء العجلات حيث يتم وزن الحيو انات كل التهات 15 يوم وتم

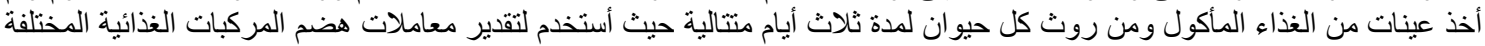
باستخدام الرماد غير الذائب كمرقم داخلي. وكانت أهم النتائج:

سجلت مجموعة الحيو انات التي غذيت على غذاء يحتوى على 80\% من الاحتياجات الغذائية حسب مقررات كيرل 1982 ( المعاملة

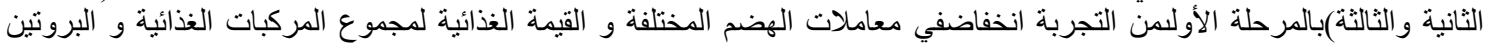

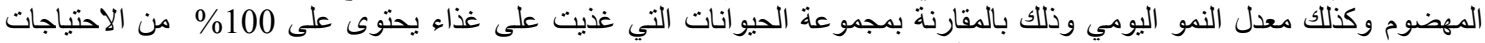

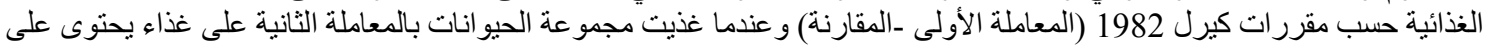

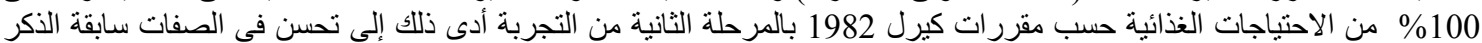

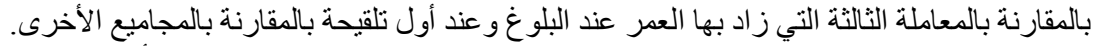

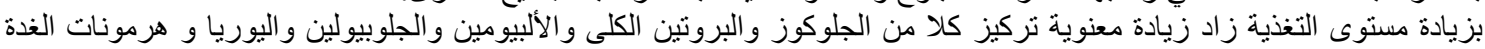
الدزية.

تحسنت الكفاءة الاقتصادية و الغذائية عموما لمجمو عة الحيو انات المجمو عة الثانية بالمقارنة بالمجاميع الأخرى.

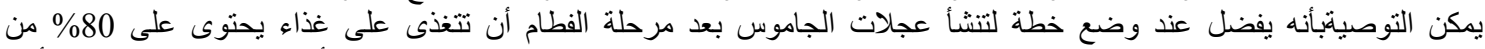

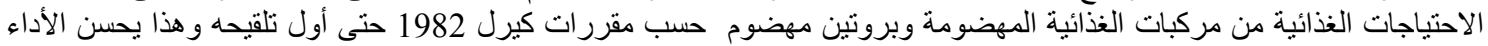

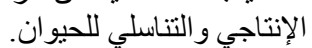

